ORIGINAL ARTICLE

Received:2020/06/2

Accepted:2020/08/15

\title{
Identifying and Prioritizing the Factors Affecting on the Implementation of Knowledge Management System (Case Study: Yazd Educational Hospitals)
}

\begin{abstract}
Ali Saffari darberazi(Ph.D.) ${ }^{1}$, Hadi Mohamadi(M.Sc. $)^{2}$, Pooria Malekinejad(Ph.D.s) ${ }^{3}$, Ali Ajdari(Ph.D. $)^{4}$
1.PhD of Industrial Management, Yazd University, Head of Research and Technology, Yazd University of Applied Science and Technology (UAST), Faculty of Economics, Management and Accounting, , Yazd, Iran.

Email:asafaari@gmail.com Tel: 09133590484

2.M.Sc. student of Information Technology Management, Faculty of Management and Accounting, Yazd University of Science and Art, Yazd, Iran.

3.PhD Student in Industrial Management, Faculty of Economics, Management and Accounting, Yazd University, Yazd, Iran.

4. PhD, Department of Accounting, Faculty of Economics, Management and Accounting, Yazd Branch, Islamic Azad University, Yazd, Iran.
\end{abstract}

\begin{abstract}
Introduction: At present, in the age of knowledge and knowledge-based, knowledge management has become particularly important. Research shows the effect of knowledge management in achieving a sustainable strategy and competitive advantage. The purpose of this study is to identify and prioritize the factors affecting the implementation of knowledge management system in educational hospitals in Yazd.

Methods: In order to conduct this research, first, using effective research background, effective factors were identified. In order to evaluate and compare the factors in relation to each other, a questionnaire was designed as a pairwise comparison and distributed among experts. In order to investigate the relationship between dimensions, the opinions of 20 experts were used. All of these people have more than 10 years of experience in this field. Then, in order to evaluate and identify the indicators, two techniques of AHP and fuzzy dimatel were used to rank the factors.

Results: According to the research findings, the highest weight is related to the organizational structure factor and the lowest weight is related to the information technology factor. Identification of the structure factor in the fuzzy dimatel technique as the most effective factor in the study with the results obtained from the fuzzy AHP alignment shows this result in the research.

Conclusion: Due to the fact that the organizational structure factor is in the highest importance compared to other factors, the need for more attention of hospital managers to this part of the knowledge management structure shows more than before.
\end{abstract}

Keywords: Knowledge Management, Knowledge Management Implementation, Yazd Educational Hospitals.

Conflict of interest: The authors declared that there is no Conflict interest.

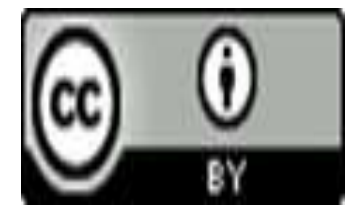

This Paper Should be Cited as:

Author: Ali Saffari darberazi, Hadi Mohamadi, Pooria Malekinejad, Ali Ajdari Identifying and Prioritizing the Factors Affecting on the Tolooebehdasht Journal.2020;19(4):52-64.[Persian] 
شناسايى و اولويتبندى عوامل موثر بر ييادهسازى نظام مديريت دانش (مورد مطالعه:

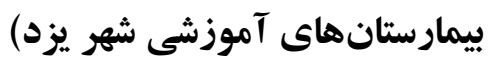

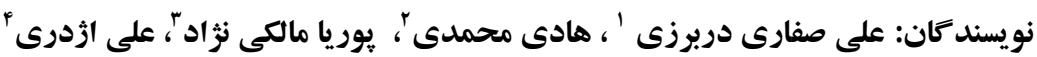

ا. نويسنده مسئول: د كترى مديريت صنعتى ، دانشكده اقتصاد، مديريت و حسابدارى،دانشكاه يزد، مسئول بثزوهش و فناورى

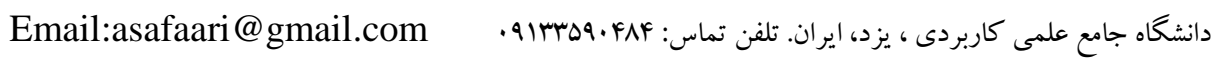

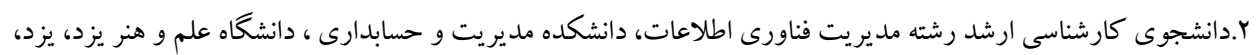

r.دانشجوى دكترى رشته مديريت صنعتى، دانشكده اقتصاد، مديريت و حسابدارى، دانشكاه يزد، يزد، ايران.

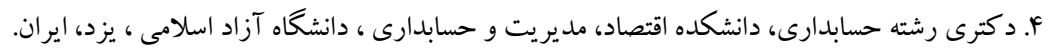

مقدمه: در حال حاضر در عصر دانايى و دانشمحورى، مديريت دانش از اهميت ويزهاى برخوردار شده است. بثوهش ها حاكى از تأثير مديريت دانش در به دست آوردن استراتثى يايدار و مزاياى رقابتى است. هدف از يزوهش حاضر شناسايى و اولويتبندى عوامل موثر بر بيادهسازى نظام مديريت دانش بيمارستانهاى آموزشى شهر يزد است.

روش بروسى: به منظور انجام اين يُزوهش در ابتدا با استفاده از مطالعه بيشينه بزٔوهش اقدام به شناسايى

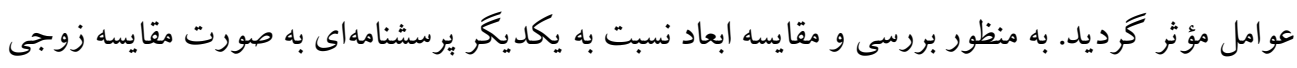
طراحى و بين خبر كان و كارشناسان توزيع شد. به منظور بررسى ارتباط ميان ابعاد از نظرات ·r نفر از خبر گان استفاده گرديد. تمامى اين افراد داراى سابقه كارى بالاى ·لا سال در اين حوزه بودهاند. در ادامه به منظور بررسى و شناسايى شاخصها به براى رتبهبندى عوامل از دو تكنيك AHP و ديماتل فازى

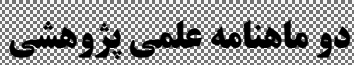

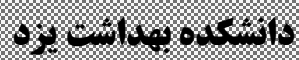

مهن

is Irव9

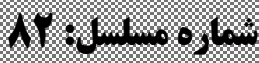
استفاده شد. يافته ها: بر اساس يافته هاى بثزوهش بيشترين وزن، مربوط به عامل ساختار سازمانى و كمترين وزن مربوط به عامل فناورى اطلاعات مىباشد. شناسايى عامل ساختار در تكنيك ديماتل فازى به عنوان اثر گذارترين عامل در يُوهش با نتايج به دست آمده از AHP فازى همسويى اين نتيجه را در يثوهش نشان مىدهد. نتيجه Fيرى: با توجه به قرارگيرى عامل ساختار سازمانى در بالاترين اهميت به نسبت ساير عوامل لزوم توجه بيشتر مديران بيمارستانى به اين بخش از ساختار مديريت دانش را بيش از بيش نمايان مىسازد. وازه هاى كليدى: مديريت دانش، ييادهسازى سيستم مديريت دانش، اولويتبندى، بيمارستانهاى آموزشى يزد.

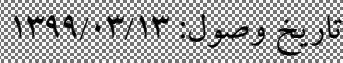

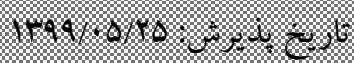


مديريت دانش به عنوان يكك مزيت برتر در مراكز آموزشى درمانى، نهادينه گُردد(Y). امروزه مديريت دانش يكى از عوامل مؤثر در موفقيت سازمانها و كسب مزاياى رقابتى به شمار مىآيد(r). از سوى ديخر به منظور اجراى موفقيت آميز يكك نظام مديريت دانش در مراكز بهاشت و درمانى، لزوم استفاده از يكك حركت جمعى و سازمانى كه طى آن همهى افراد در

ردههاى مختلف در گير شوند، خود را نمايان مىسازد (F). استفاده از يكك سيستم مديريت دانش داراى تفاوتهاى بسيار زيادى از حيث اجرا در ميان سازمانهاى بهداشتى و درمانى با ساير سازمانهاست. يكى از تفاوتهاى اين بخش، وجود اهدافى فراتر از اهداف سازمانهاى ديخر يعنى ارتقاى مراقبت از بيمار و كاهش خطاهاى يزشكى است و تفاوت ديخر، استفادهى فزاينده از فن آورىهاى بيشرفته در خدمات بهداشتى است كه استفاده و به كار گيرى مناسب كار كنان آموزش ديده و متخصص را ضرورى مى سازد. از طرف ديخر لزوم انجام كار به صورت گروهى و حول محور بيمار، لزوم به اشتراك گذارى هر جه بيشتر دانش و سازماندهى بهتر آن را نمايان مىسازد. به منظور ايجاد تنوع در فعاليتها و تخصصىسازى آنها در سازمانهاى بهداشتى - درمانى، مىبايست دانش سازمانى را از طريق طرحهاى هوشمندانه و ابزارهاى عصر اطلاعات، شناسايى، جمع آورى و به اشتراكى گذاشته شود(ه). در عصر بر حاضر كه به عصر دانايى و دانشمحورى معروف است، مديريت دانش از اهميت ويزهاى برخوردار شده است. استفاده مناسب از مديريت دانش، مديران را قادر خواهد ساخت، به افزايش سطح دانش و توانمندى كاركنان كمك نمايند و با
امروزه ارزش دانش بر كسى بوشيده نيست. فرهنگكهاى قوى و متمدن جهه در گذشته و جِه در حال حاضر، همواره بر بايه دانش بنا گرديدهاند. در گذشته، كليد اصلى توليد ثروت، مالكيت و دسترسى مناسب به سرمايه و منابع طبيعى بود؛ اما امروزه، كليد اصلى ثروت در جوامع، به ميزان دسترسى سازمانها و نهادهاى مختلف به ايجاد دانش برمى گردد. از سويى ديخر در كذشته قطع درختان، معدن طلا، يا آهنگرى مىتوانست به توليد ثروت بيانجامد اما اكنون به منظور توليد ثروت تمام بخشهاى يكى جامعه و حتى يكك سازمان به خدمات همديخر نيازمندند تا به يكك توليد مناسب دست يابند. اغلب شر كتهاى بزرگى، امروزه به دليل استفاده مناسب از مهارتها و تجارب نيروى كارشان به سوى موفقيت در حال بيشرفتند؛ در صورتى كه شايد دارايى فيزيكى مناسبى را در اختيار نداشته باشند(1). مديريت دانش با استفاده مناسب از تجربيات افراد سازمان و قراردادن اين تجربيات در اختيار تمامى اعضاى سازمان به استفاده مناسب افراد بدون محدوديت زمانى و مكانى به دانش ساير اعضاى سازمان كمك شايان توجهى مىنمايد. از اين رو مديريت دانش، نقش مهمى در بهبود اثربخشى و كارايى سازمانها مىتواند ايفا نمايد. مديريت دانش يكى از عوامل حياتى است كه بخش قابل توجهى از يُزوهشهاى حوزه بهداشت و درمان را به خود اختصاص داده است، و لزوم استفاده از آن را نمايان مىسازد. افزايش قابل ملاحظه نشريات مديريت دانش گُواه اين موضوع است. از آن جا كه، مديريت دانش با فرهنگك سازمانى و تمامى مؤلفههاى آن ها باهم رابطه مثبت و معنى دارى دارند، مىتوان با برنامهريزى در زمينه ابعاد فرهنك سازمانى به تدريج تعامل بين 
در سازمانهاى بهداشتى و درمانى نيز مشابه ساير سازمانها، دانش زيادى در وراى فرايندها توليد مىشود. وجود دانش بسيار زياد در سيلوهاى دانشى افراد در سازمانهاى بهداشتى درمانى موجب مى گردد تا لزوم بهره گيرى مناسب از اين دانشها كه در حقيقت از فرايندهاى سازمان خارج شدهاند، بيش از ييش خود را نمايان سازد.جابجايى منابع انسانى و خروج آن ها از سيستم به اشكال مختلف به خروج سرمايههاى فكرى مىانجامد و اين بدان معنى است كه بايد منابع محدود سازمانى را به كار كرفت و هر روز از نو تجربه كرد. هر جند با به كارگيرى سيستمهاى اطلاعاتى، دادهها و اطلاعات در درون اين سازمانها تا حدودى مهار شده است، اما تحت كنترل در آمدن دادهها و اطلاعات و به بيان ديخر اجراى مديريت اطلاعات به مفهوم استفادهى مؤثر از دانش سازمانى نيست. ازآنجايى كه شرط اصلى در اجراى مأموريتهاى سازمان تصميم گيرى مىباشد و عدم قطعيت يكى از معمول ترين مسائل تصميم گيرى است. سازمانهاى بهداشتى و درمانى نيازمند جمع آورى و تحليل دادهها و تبديل آنها به

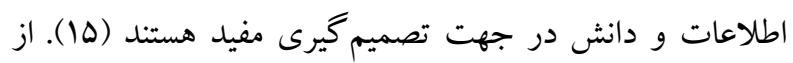
اين رو ئزوهش حاضر درصدد شناسايى و رتبه بندى عوامل مؤثر ييادهازى سيستم مديريت دانش با استفاده از تكنيككهاى تصميم گيرى جند معياره است.

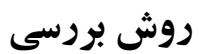

اين تحقيق از باب هدف يزوهشى كاربردى است و در دسته تحقيقات توصيفى قرار مى گيرد كه به صورت بيمايشى صورت بذيرفته است. به منظور انجام اين يُزوهش در ابتدا با استفاده از مطالعه بيشينه بُزوهش به شناسايى عوامل مؤثر بر موفقيت در ييادهسازى يكك سيستم مديريت دانش گرديد. سِّ با استفاده
استفاده از دانش سازمانى به تصميم گيرى بهتر در حوزههاى مختلف نائل آيند. به منظور نهادينهسازى مديريت دانش در سازمانها مىبايست با اهميتدادن به آموزش صحيح، فرهنك سازى مطالعه و انتقال تجربه و دانش در بيمارستانها و دانشگاهها، فرهنگ آموزش و كار مشار كتى نهادينه گردد(9). مديران از روشهاى مناسب و مهارتهاى ارتباطى بهرهيرى نمايند و تعاملات فردى و سازمانى با يكديخر داشته باشند. شايسته سالارى وتوجه به توانمندى مديران، اطلاعرسانى مناسب و حركت مديران به سمت فرايندهاى مشاركتى و تيمى مىتواند موانع انتشار دانش را مرتفع كند (V). ئزوهشها حاكى از تأثير مديريت دانش در به دست آوردن استراتزى بايدار و مزاياى رقابتى است (N). مديريت دانش در كسب مزاياى رقابتى و توسعهى بايدار نيز نقش عمدهاى ايفا مى كند(9). امروزه بسيارى از مديران سازمانها در بيى استقرار سيستم مديريت دانش براى تسهيل فعاليتهاى مديريت دانش و بهرهگيرى از آن هستند، و با توجه به اهميت مديريت دانش، به بيادهسازى و توسعه سيستم مديريت دانش، توجه به موضوعها و جالشها و عوامل مؤثر در موفقيت بيادهسازى سيستم مديريت دانش، توجه ويزهاى دارند

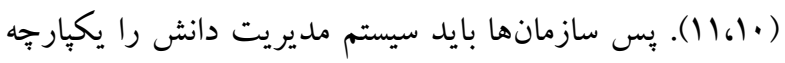
نموده و دانش سازمان را جمع آورى، دستهبندى، سازماندهى، ذخيره، اشتراكك و در سطح سازمان در دسترس، قرار دهند. درنتيجه اجراى مديريت دانش در سازمان موجب مىشود تا دانش توليد شده توسط افراد براى هميشه در سازمان باقى بماند

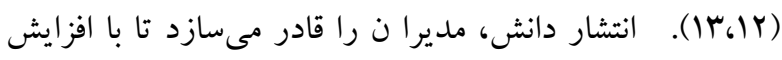
سطح دانش و توانمندىهاى خود، در تصميم گيرى بهتر عمل

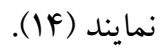


تصميم گيران بسته به موضوع تحقيق و با توجه به نتايج بهدستآمده، درصدد باشند تا به نتايج زودبازده، اما سطحى دست يابند، مىتواند بر اولويتهاى قرارگرفته در گروه تأثيريذيرها تمركز نمايند. حال اكر هدف اين تصميم انجام اقدامات اساسى يا تمركز بر اصل و بِايه موضوع باشد، مى تواند بر اولويتهاى قرار گرفته در لايه تأثير كذارها يا علتها تمركز نموده و برنامهاى خود را متناسب با آن تدوين نمايند. اين مساله هنگامى كه تكنيك با رويكرد فازى آميخته شود دقت و اعتبار بيشترى بيدا كرده و نتايج مستدل ترى ارائه مىنمايد. در اين يُزوهش بِ از بررسى ادبيات و يُّوهشهاى صورتيذيرفته و بر اساس نظر خبر كان، عوامل موثر در بيادهسازى سيستم مديريت دانش در ها بعد و \ا شاخص تعيين و مشخص گرديد كه در ذيل به توضيح مختصرى از هر بعد برداخته شده و سبس در جدول ا كليه زيرشاخصهاى مربوط به - مهر بعد آورده شده است.

فرهنك سازمانى (Organizational Culture) يكى از اساسىترين عوامل براى موفقيت سيستمهاى مديريت دانش است كه عبارت است از ارزشها و هنجارهاى مشترك در سازمان و كاركنان سازمان، كه رابط بين آنها بوده و نحوه انجامشدن كارها در سازمان را مشخص مى كند. به عبارتى فرهنگ فازمانى، هويت اجتماعى هر سازمان را مشخص مى كند (10-IV) ( ) با توجه به حمايتى كه فرهنگ از مديريت دانش به عمل مى آورد و براى دانش و ايجاد آن ارزش قائل مىشود، كار كنان را به اشتراكى كذاشتن و كاربرد دانش، تشويق مى كند (1) (1). ساختار سازمانى (Organizational Structure)، يكى از عواملى است كه در بهكارگيرى فنآورىهاى جديد در
از نظرات هـ تن از اساتيد دانشخاهى اقدام به تعديل و بومىسازى اين عوامل گرديد. به منظور بِاسخدهى به سؤالات يرسشنامهاى طراحى شده در اين يزوهش از نظرات بr تن از خبر كان صنعت بهداشت و درمان استان يزد استفاده شد. اين نفرات از طريق نمونه گيرى كلولهبرفى در يُزوهش شناسايى شدند. براى سنجش روايى از نظرات خبر كان و هم جِنين براى سنجش پِيايى يرسشنامه از آلفباى كرونباخ استفاده شده است. قلمرو مكانى و موضوعى اين تحقيق اولويتبندى عوامل مؤثر در بيادهسازى سيستم مديريت دانش در بيمارستانهاى آموزشى يزد مىباشد. اين يزووهش در 9 ماهه دوم سال \هَا انجام يافته است. در اين يُزوهش براى اولويتبندى عوامل مؤثر در بِيادهازى سيستم مديريت دانش از رويكرد تلفيقى AHP فازى و DEMATEL فازى استفاده مىشود. بِ از آنكه وزن هر شاخص از روش فازى به دست آمد، با ضرب آنها در مقادير D+RP بهدست آمده از روش Dهر بعد و شاخص از لحاظ علت يا معلول بودن بررسى مىشود بهنحوى كه شاخصهايى كه مقادير D-R مثبت دارند، شاخصهاى تأثير گذار يا علت مىباشند و مقادير منفى، شاخصهاى معلول و تأثيريذير مىباشند. ساختار اين رويكرد به گونهاى است كه طى آن مىتوان عوامل مؤثر در بيادهسازى موفق سيستم مديريت دانش را به دو دسته از حيث تأثير گذارى و تأثيريذيرى، دستهبندى نمود. يعنى اين تكنيك علاوه بر امكان اولويتبندى عوامل، اين امكان را نيز براى مديران و تصميم گيران محقق مىسازد كه سرمايه و زمان خود را براى برداختن به نتايج بزوهش، مديريت نموده و به شكل هوشمند و هدفدار به حركت ادامه دهند. به عبارتى 
نياز كاربران بودن، مرتبطبودن محتويات دانشى بودن، استانداردسازى ساختار و هستىشناسى (Ontology) دانش است (YN). بدون فناورى اطلاعات امكان ذخيرهسازى اطلاعات وجود ندارد و از آن جايى كه ذخيرهسازى يكى از اصلىترين فرايندهاى مديريت دانش است، ضعف در اين فرايند منجر به

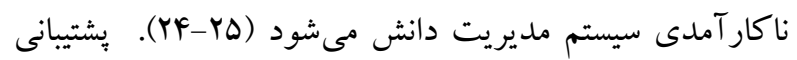
مديريت ارشد نيز يكك اصل ضرورى به منظور موفقيت در برنامههاى مديريت دانش از يكك سو و ايجاد تعهد راهبردى مستمر به توليد دانش توسط مديران عالى و ارشد سازمان از سوى ديخر است. همجنين رهبرى در عرصه مديريت دانش بايد نشاندهنده ويز گىهاى خاصى باشد كه به مديريت دانش منجر

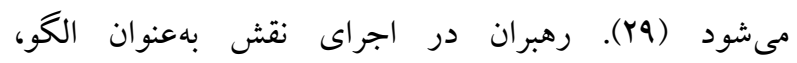
منعكس كنندهى رفتار مديريت دانش هستند و بايستى بهصورت مستمر بيآموزند و دانشها و ايدهاى جديد را جست و جو كند (N). مديران ارشد نقش مؤثرى بر ديخر عوامل موفقيت بيادهازى سيستم مديريت دانش نظير فرهنگكازى مناسب، طراحى برنامههاى آموزشى و تشويق كار كنان براى شركت در اين برنامهها و... را بر عهدهدارند. اين يُوهش با رعايت ملاحظات اخلاقى در كميته سازمانى اخلاق در دانشكاه علوم بز شكى شهيد صدوقى يزد با كدIR.SSU.REC.1399.186 مورد بررسى و تصويب قرار

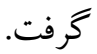

يافتهها

عوامل مؤثر بر موفقيت در بيادهازى سيستم مديريت دانش در بيمارستانها بر اساس بيشينه يزوهش جمع آورى گرديده است كه در جدول ا نشان داده شده است.
مديريت دانش نقش مهمى ايفا مى كند و مىتواند با تعريف وظايف مختلف و هماهنك نمودن اين وظايف، ساختارى براى سازمان تعريف كند (9). ازجمله شاخصهاى مهم در ساختار سازمانى رسميت، عدم تمركز و بِيجِيدگى مىباشد كه تأثير زيادى بر هماهنكى و همكارى درون شركت و ايجاد دانش دارند (1)). منابع انسانى در يكك سازمان بيان مىدارد كه افراد در سازمانها، بهعنوان ابزار انسانى شامل: مهارت، نقشهاى دانشى، انخيزش و تقويت شبكههاى يادگيرى و خلاقيت مطرح مىباشند (•r- ه1). از طرف ديخر ايجادكند گان دانش در سازمان نيز مىباشند زيرا يكك قسمت قابل توجه از دانش سازمان در ذهن افراد مىباشد (YI). درحالى كه به دلايل متعدد منابع انسانى براى مديريت دانش نقش اساسى دارد، تمركز اصلى بر موضوعات استخدام كار كنان، توسعه و نخهارى آنها مىباشد. استخدام مؤثر كار كنان حياتى است و بايستى بر توانايى داوطلبان در تطبيق با فرهنك سازمان با روش ويزهاى، بهجاى تطبيق آنها با مشخصات شغل، تمركز كرد (TYYYY) . زير ساختهاى فناورى اطلاعات بدون شك يكى از محركهاى دانش، فناورى اطلاعات است كه مىتواند مجموعهاى از نقشها را براى يشتيبانى از فرايندهاى مديريت دانش ايفا كند (YQ-YF). نقش زيرساختهاى فناورى در مديريت دانش را مىتوان به عنوان، يشتيبانى از مخازن دانش، افزايش دسترسى، تبادل دانش و تسهيلات محيط دانش دانست كه منجر به تعاملات فردى، گروهى و سازمانى مى گردد و به واسطه ابزارى به فرايندهاى ايجاد دانش در محيطهاى علمى كمكك مى كند (YV-YY). از مهمترين مواردى كه در بيادهسازى سيستمهاى مديريت دانش بايد مدنظر قرارداد، سادكى تكنولوزى مورد استفاده، متناسب با 
جدول ا: ابعادو عوامل موثر در ييادهسازى سيستم مديريت دانش

\begin{tabular}{|c|c|}
\hline شاخصها & ابعاد \\
\hline اعتماد & فرهنگ فازمانى \\
\hline \multicolumn{2}{|l|}{ همكارى } \\
\hline \multicolumn{2}{|l|}{ جو باز } \\
\hline \multicolumn{2}{|l|}{ تسهيم و به اشتراك گذاشتن دانش } \\
\hline \multicolumn{2}{|l|}{ خلاقيت و نو آورى } \\
\hline تمركز & ساختار سازمانى \\
\hline \multicolumn{2}{|l|}{ رسميت } \\
\hline \multicolumn{2}{|l|}{ 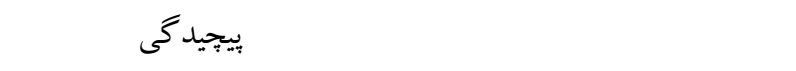 } \\
\hline \multicolumn{2}{|l|}{ مستندسازى } \\
\hline مشار كت كار كنان & منابع انسانى \\
\hline \multicolumn{2}{|l|}{ آموزش كار كنان } \\
\hline زير ساختهاى شبكه و سختافزار & زيرساختهاى \\
\hline دسترسى به نرمافزارهاى كاربردى & فناورى اطلاعات \\
\hline \multicolumn{2}{|l|}{ كار كنان فناورى اطلاعات } \\
\hline \multicolumn{2}{|l|}{ فناورى هاى همكارى } \\
\hline سياستهاى باداش & رهبرى و حمايت \\
\hline راهبرد دانش & 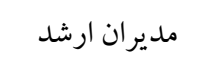 \\
\hline حذف محدوديتهاى سازمان & \\
\hline
\end{tabular}

مقايسات زوجى بـ از قطعى كردن اعداد فازى، ماتريسهاى مقايسات زوجى ابعاد و شاخصها تعيين شد. سبس به بررسى نرخ ناساز كارى هريكك از ماتريسها برداخته شد. نتايج نشان داد كه نرخ ناسازگارى هر شش جدول مقايسات زوجى، كمتر از //• مىباشد. در ادامه با استفاده از ميانخين هندسى مقايسات زوجى خبر كان و وزن فازى آنها به صورت يك جدول كلى بدست مى آيد. وزن نهايى براى هر سه بيمارستان آموزشى يزد در جدول ب نشان داده شده است. در ادامه با استفاده از تكنيك DEMATEL فازى اقدام به بررسى اثر گذارى و اثريذيرى ابعاد در ارزيابى ابعاد بيادهسازى مديريت دانش بيمارستانهاى آموزشى يزد گرديده است. سال نوزدهم:شماره جهارم ، مهر و آبان
همانكونه كه در قسمت روششناسى بزوهش بيان گرديد، جهت تعيين عوامل مؤثر بر موفقيت بيادهسازى سيستم مديريت دانش، ابتدا با بررسى ادبيات تحقيق و مطالعات مشابه، مجموعهاى از عوامل شناسايى گرديد. سبس با انجام مصاحبه با خبر كان عوامل نهايى مؤثر، در قالب بنج بعد و \ا شاخص تعيين گرديد بر اساس جدول ا درخت سلسلهمراتبى تحقيق شكل گرفت. سبّ با استفاده از درخت سلسله مراتبى تصميم شكل گرفته، يرسشنامه مقايسات زوجى طراحى و بين خبر كان و كارشناسان بخش درمان بيمارستانهاى آموزشى يزد توزيع گرديد. بس از كردآورى دادههاى كلامى، دادههاى مذكور مطابق با جدول r تبديل به اعداد فازى گرديد. جهت بررسى ساز گارى ماتريس دو ماهنامه علمى يزروهشى طلوع بهداشت يزد 
$\Delta q$

دقيق، مخصوصاً در شرايط عدم قطعيت، بسيار دشوار است، جراكه نتايج تصميم گيرى بهشدت به داورىهاى ذهنى غيردقيق و مبهم وابسته است. اين عامل باعث نياز به منطق فازى در ديمتل شده است (Yr). در اين ثئوهش در بخش تكنيك ديمتل فازى از متغيرهاى زبانى فازى مثلثى استفاده شده است. بدين منظور در ابتدا به ايجاد ماتريس اوليه روابط مستقيم (A) تيرداخته شده است. برسشنامه مربوط به سطح نفوذ هر شاخص به ديگر شاخصها تهيه و بين خبر گان توزيع مى گردد و پيس از جمع آورى نظرات خبر كان و با استفاده از جدول سا، دادهاى كلامى به اعداد فازى تبديلشده و با استفاده از رابطه (1) ماتريس اوليه روابط مستقيم تعيين مى گردد.

روش ديمتل اولين بار توسط دو بزٔوهشگر به نام هاى فونتلا و كابوس در سال 19V9 ارائه شد. اين تكنيك از انواع روشهاى تصميم گيرى بر اساس مقايسههاى زوجى است( •r). اين تكنيك با بررسى روابط متقابل بين معيارها، ميزان تأثير و اهميت آنها را بهصورت امتياز عددى مشخص مى كند. مهمترين شاخصه روش ديمتل تصميم گيرى جندمعياره و عملكرد آن در ايجاد روابط و ساختار بين عوامل مىباشد. اين تكنيك علاوه بر تبديل روابط علت و معلولى به يكك مدل ساختارى - بصرى، قادر است وابستخى هاى درونى بين عوامل را نيز شناسايى و آنها را قابل فهم كند ( آس). با اين حال بهطور كلى، بر آورد نظر خبر گان با مقادير عددى جدول r: وزن نهايى هر كدام از ابعاد براى هر سه بيمارستان آموزشى يزد با استفاده از AHP فازى

\begin{tabular}{|c|c|c|c|c|c|c|}
\hline \multicolumn{6}{|c|}{ وزن دىفازى } & \multirow[t]{2}{*}{ ابعاد اد } \\
\hline 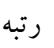 & بيمارستان C & رتبه & بيمارستان & رتبه & بيمارستان A & \\
\hline f & .119 .9 & r &.$/ 19 \vee \wedge$ & f & ./llovar & فرهنگ سازمانى \\
\hline 1 & $\cdot / r V V$ & 1 & $\cdot / 4 \cdot .9$ & r & - ITFTIFA & ساختار سازمانى \\
\hline$r$ &.$/ 19 V F$ & $r$ & - /NAFq & 1 & 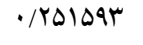 & منابع انسانى \\
\hline$\Delta$ & $.1 .9 F F$ & $\Delta$ & 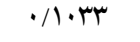 & $\Delta$ & $\cdot 1 \cdot$ VYFIQ & فناورى اطلاعات \\
\hline r & • TYMAY & f & $\cdot / I F V F$ & r & $\cdot / / \& q V \cdot \Delta$ & حمايت مديران \\
\hline
\end{tabular}

جدول س: الكوى مقياس كلامى فازى تأثير هر متغير در متغير ديخر

\begin{tabular}{|c|c|c|c|c|c|}
\hline تأثير خيلى زياد & تأثير زياد & تأثير كم & تأثير خيلى كم & بدون تأثير & عبارات كلامى \\
\hline F & $r$ & r & 1 & · & مقياس عددى \\
\hline$(\cdot / \cdot 6 / / 1,9)$ & $(\cdot / \cdot 6 \Delta / \cdot 6 / 9 / 9)$ & $(\cdot / \cdot \sigma / / \cdot \Delta / V)$ & $(\cdot / \cdot \sigma / / \cdot \sigma / \Delta)$ & $(\cdot 6 \cdot / \cdot 61 / \Gamma)$ & اعداد فازى مثلثى \\
\hline
\end{tabular}


4.

در ادامه با استفاده از نظرات خبر كان اقدام به نرمالسازى نتايج فازى شكل گرفت. نتايج نهايى به دست آمده حاصل از اين بدست آمده گرديده است. در ادامه با استفاده از ماتريس نشان داده شده است.

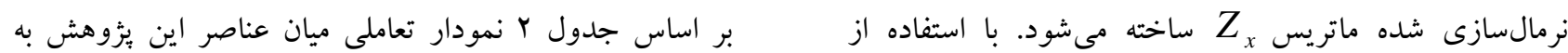

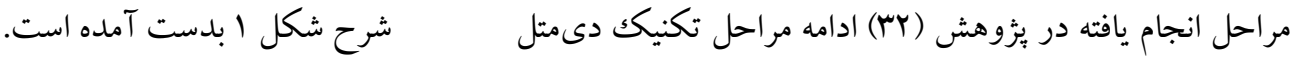

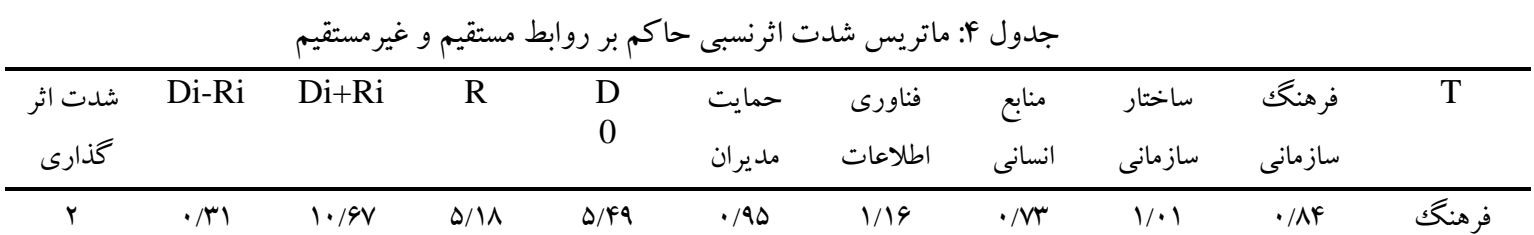

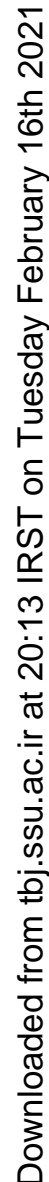

Aازمانى

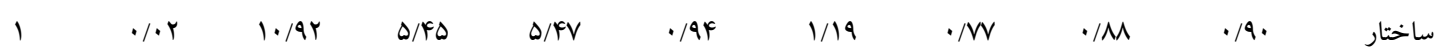
سازمانى

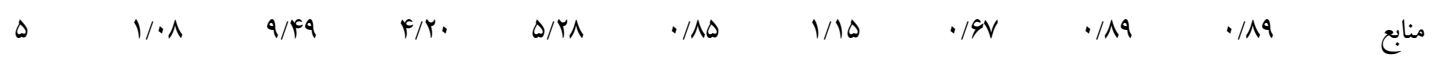
C انسانى

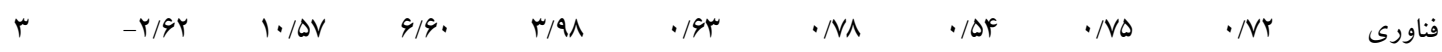
Dاطلاعات

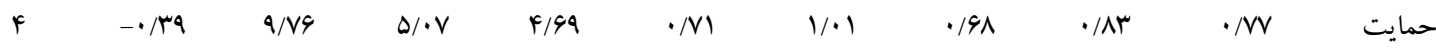
مديران

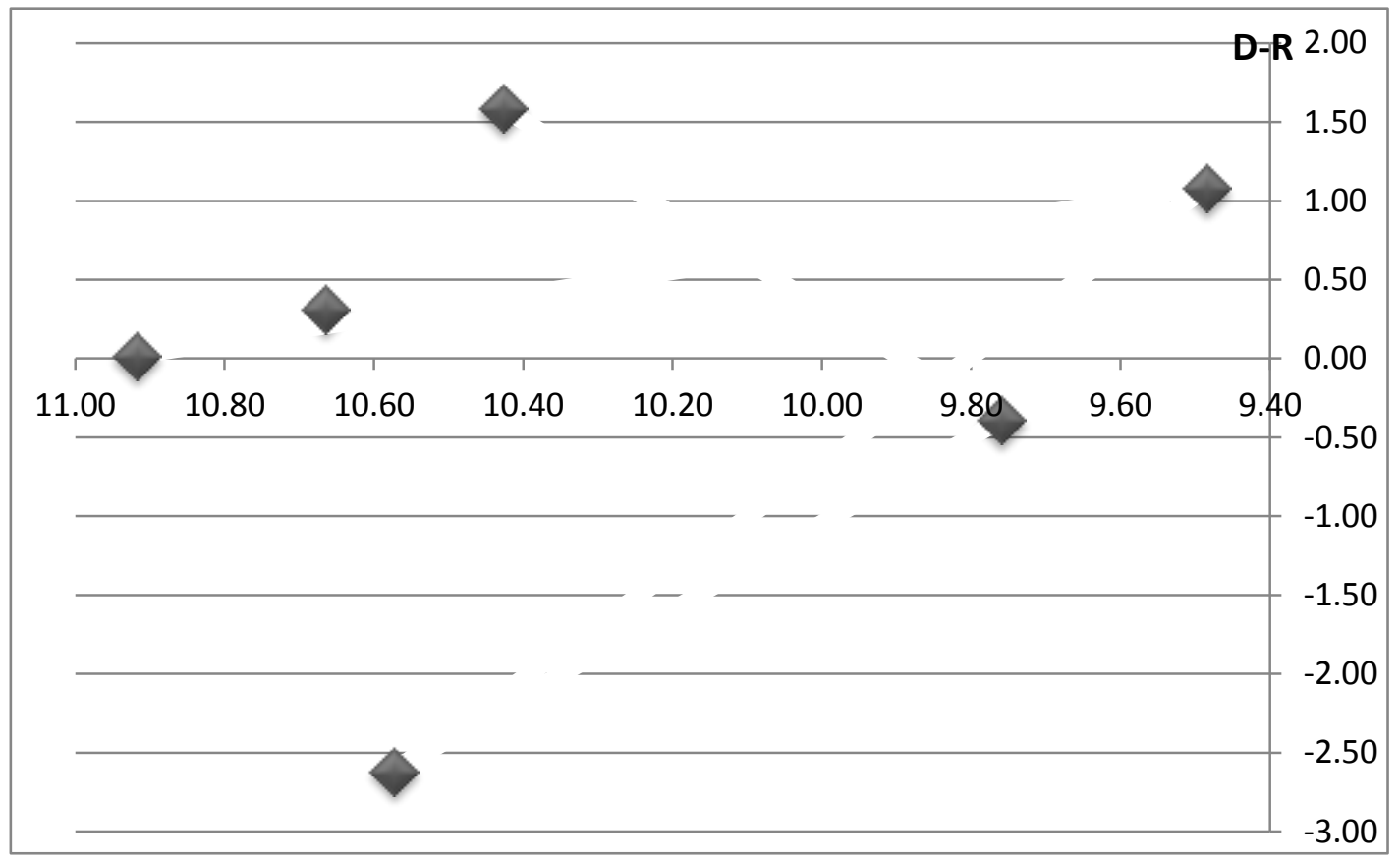

شكل ا. نمودار على شاخصهاى بيادهسازى مديريت دانش در بيمارستانهاى آموزشى يزد 
اطلاعاتى بيمارستان و نيز فقـدان يكك پِت سازمانى مرتبط با فعاليـهـاى اطلاعـاتى در گخروه مـديريت ارشد بيمارستان از جمله ايـن مـسائل اسـت. ايـن مسائل نسشان مىدهند كه ساختار سازمانى فعلى بخش مدارك بز شكلى در ايـران براى مديريت كار آمد اطلاعات مراقبت بهداشتى مناسب نيست و نيز حوزههاى قدرتمندى براى ارائه خدمات جامع مديريت اطلاعـات در بيمارستانهاى ايران وجود ندارد. ايـن مسائل مسىوانـد منجر بـه انحراف و ضعف بخش مداركك يزشكى در راستاى اهداف اصلى خـود كردد. بنابراين تجديد ساختار سازمانى اين بخش ضـرورى بـه نظر مىرسد. در حالى كه در كشورهاى بيشرفته براى انعكاس اهـدف و وظايف رو به رشد اين بخش از عنـاوينى ماننـد مـــيريت اطلاعـات بهلداشتى استفاده مىشود. با توجه به يافتهاى يُزوهش و تائيد نيازسنجى آموزشى بيشنهاد مىشود كه دورهها با توجه به نيازها و واقعيتهاى بيمارستانهاى آموزشى طراحى شود و آموزش و ياد گيرى با نيازهاى آموزشى شغلى ساز گار باشد. با توجه به يافتهاى بززوهش بيشنهاد مى شود كه از رويكردها، مدلها، روشها و فناورىهاى نوين مديريت استفاده و نقاط قوت و ضعف ارزيابى شود و نقايص مرتفع و نقاط مثبت تقويت گردد. با توجه به يافتهاى يُزوهش ويشنهاد مىشود كه اهرمهاى تشويقى و اعطاى امتيازات جهت ترغيب كادر درمانى بيمارستانهاى آموزشى به كار گرفته شود.

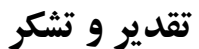
نويسند كان اين مقاله بر خود لازم مىدانند از كليه اساتيد گرامى كه در راستاى انجام اين بُزوهش مشار كت داشتهاند سباسكز ارى نمايند.
در مرحله اول براى به دستآوردن تعيين وزنهاى فازى كلى عوامل مهم در بيادهسازى نظام مديريت دانش در بيمارستانهاى آموزشى يزد از تكنيك AHP فازى استفاده شده است. نتايج به دست آمده نشان داد كه بالاترين وزن مربوط به ساختار سازمانى و كمترين وزن به عامل فناورى اطلاعات مربوط است. يافتهها نشان داد كه ساختار سازمانى داراى اهميت بالايى در بيادهسازى

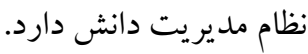
نتابج اين يُزوهش نشان مىدهد كه در حال حاضر ساختار سازمانى كليه بيمارستانهاى آموزشى كاملاً متمركز بوده و تمركز بيش از حد ساختار سازمانى سبب مى گردد كه تصميم گيرىهاى مديريتى عموماً در خارج از بيمارستان اتخاذ كردد و تا مر حله اجرا تسرى يابد. يافتهاى اين بخش از يُزوهش با نتايج به دست از تحقيق (V) همسو است. نتايج AHP فازى براى هر بيمارستان نشان داد كه ساختار سازمانى تقريباً از رتبه بالا و فناورى اطلاعات از رتبه بايينى

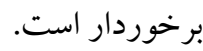
نتايج ديماتل فازى نشان داد كه اثركذارترين معيار ساختار سازمانى مىباشد كه با نتاج به دست آمده از AHP فازى تقريباً همسويى را نشان مىدهد كه اين بيان مى كند كه مقايسه ساختار سازمانى بخش مـدارك يزّـكى و فعاليتهـاى اطلاعاتى در بيمارستانهاى ايران با كشورهاى بيشرفته، نقاط ضعف ساختار سازمانى اين بخش را در ايران آشكار مسىسازد. استفاده از عناوين بسيار زياد و نامناسب، فقـدان برخى از وظايف، واحسدها و فعاليتهاى حائز اهميت در اين بخش، جايخَاه سـازمانى نامناسـب اين بخش در تشكيلات بيمارستانها، 


\section{References}

1-Srivastava SK, Chandra B, Srivastava P, editors. The Impact of Knowledge Management and Data Mining on CRM in the Service Industry2019; Singapore: Springer Singapore.

2-Donyayi NJT. The Relationship between Nurses Knowledge Management and Organizational Culture in Teaching Hospitals of Iran University of Medical Sciences.2020;18(6):59-69.

3-Tabibi SJD, Nasiri Pour AA, Aghababa S, Nabi pour jafar abad N. The Study OF Knowledge Management Principles in Teaching Hospitals Associated With Iran University of Medical Sciences. 2011;8(4 (20)):469 -78.

4-Tuffrey-Wijne I, Giatras N, Goulding L, Abraham E, Fenwick L, Edwards C, et al. Identifying the factors affecting the implementation of strategies to promote a safer environment for patients with learning disabilities in NHS hospitals: a mixed-methods study.2013.

5-Imani-Nasab MH, Nouraei Motlagh S, Bastani P, Birjandi M, Bakhtiar K, Samadbeik M. Knowledge Translation at Lorestan University of Medical Sciences: Evidence from Iran. 2020;21(5):e90509.

6-Ayatollahi H, Zeraatkar K. Factors influencing the success of knowledge management process in health care organisations: a literature review. 2020;37(2):98-117.

7-Heydaripur M, Yazdanpanah AJTJoT. Analyzing the Barriers to Knowledge Distribution in Hospital Managers A qualitative study in Educational Hospitals in Shiraz and Kerman. 2019:61-82. 8-Jafari M, Akhavan P, Rezaee Nour J, Fesharaki Mehdi N. Knowledge management in Iran aerospace industries: a study on critical factors. Aircraft Engineering and Aerospace Technology. 2007;79(4):375-89.

9-Jasimuddin Sajjad M. A holistic view of knowledge management strategy. Journal of Knowledge Management.2008;12(2):57-66.

10-Maditinos D, Chatzoudes D, Tsairidis C, Theriou G. The impact of intellectual capital on firms' market value and financial performance. Journal of Intellectual Capital.2011;12(1):132-51.

11-Ngai EW, Chan EJEswa. Evaluation of knowledge management tools using AHP. 2005;29(4):889-99.

12-Burk MJPR. Knowledge management: everyone benefits by sharing information.1999;63(3). 
13-Maldonado-Guzmán G, Lopez-Torres Gabriela C, Garza-Reyes Jose A, Kumar V, MartinezCovarrubias Juan L. Knowledge management as intellectual property: Evidence from Mexican manufacturing SMEs. Management Research Review. 2016;39(7):830-50.

14-Long D, Fahey L. Diagnosing cultural barriers to knowledge management. 2000;14(4):113-27.

15-Islam MA, Agarwal NK, Ikeda MJIj. Effect of knowledge management on service innovation in academic libraries.2017;43(3):266-81.

16-Robbins SP, Judge TJIuSR. Organizational Behavior: New Jersey: Printice Hall. 2003.

17-Goh SCJJokm. Managing effective knowledge transfer: an integrative framework and some practice implications.2002;6(1):23-30.

18-Chase RLJJoKM. The knowledge-based organization: an international survey. Journal of Knowledge Management.1997;1(1):38-49.

19-Gold AH, Malhotra A, Segars AHJJomis.Knowledge management:An organizational capabilities perspective.2001;18(1):185-214.

20-Moffett S, McAdam R, Parkinson S. An empirical analysis of knowledge management applications. Journal of Knowledge Management.2003;7(3):6-26.

21-Chuang CH, Jackson SE, Jiang YJJom. Can knowledge-intensive teamwork be managed? Examining the roles of HRM systems, leadership, and tacit knowledge. 2016;42(2):524-54.

22-Zheng W, Yang B, Mclean Gnjjobr. Linking organizational culture, structure, strategy, and organizational effectiveness: Mediating role of knowledge management.2010;63(7):763-71.

23-Yahya S, Goh WK. Managing human resources toward achieving knowledge management. Journal of Knowledge Management. 2002;6(5):457-68.

24-Lambert DM, Cooper MC, Pagh JDJTijolm. Supply chain management: implementation issues and research opportunities. 1998;9(2):1-20.

25-Luthra S, Garg D, Haleem AJJoCP. The impacts of critical success factors for implementing green supply chain management towards sustainability: an empirical investigation of Indian automobile industry. 2016;121:142-58.

26-Liebowitz J, Frank M. Knowledge management and e-learning: CRC press; 2016.

27-Tan CN-LJHe. Enhancing knowledge sharing and research collaboration among academics: the role of knowledge management.2016;71(4):525-56. 
af

28-Mohammadi K,Khanlari A,Sohrabi Bjijokm.Organizational readiness assessment for knowledge management.2009;5(1):29-45.

29-Leon RD, Romanelli M, editors. Rethinking Romanian and Italian Smart Cities as KnowledgeBased Communities2020; Cham: Springer International Publishing.

30-Trevithick S, Flabouris A, Tall G, Webber CJR. International EMS systems: New South Wales, Australia. 2003;59(2):165-70.

31-Wu W-WJESwA. Choosing knowledge management strategies by using a combined ANP and Dematel approach.2008;35(3):828-35.

32-Abdullah L, Zulkifli Njesw A. Integration of fuzzy AHP and interval type-2 fuzzy Dematel: An application to human resource management.2015;42(9):4397-409. 